\begin{tabular}{|l|l|l|l|}
\hline Received 12/02/2019 & Published 22/04/2019 \\
\hline
\end{tabular}

\title{
Public Policy Advocacy Process on the Protection of Indonesian Migrant Workers conducted by Institute for Education Development, Social, Religious, and Cultural Studies (INFEST)
}

\author{
Laras Ningrum Fatmasiwi \\ Email: larasningrum9@gmail.com
}

Universitas Muhammadiyah Yogyakarta, Yogyakarta, Indonesia

\section{ABSTRACT}

This article describes the working patterns of local NGO networks for the advocacy of Indonesian Migrant Workers/Pekerja Migran Indonesia (PMI). INFEST (Institute for Education Development, Social, Religious, and Cultural Studies) together with Network of Migrant Workers/Jejaring Buruh Migran (JBM) collaborated to develop a proposed bill to amend the article on Protection of Indonesian Migrant Workers. Nowadays, a lot of cases regarding the protection of migrant workers has not been fulfilled

Keywords

INFEST; Advocacy Network; Indonesian Migrant Workers; Network of Migrant Workers due to less attention of Indonesian government to provide a proper law on the protection of migrant workers. The author uses the nine-step advocacy approach described by Roem Tomatimasang, which forms the core circle, selects strategic issues, designs goals and strategies, processes data and packs information, mobilizes allies and advocates, submits counter draft, influences policymakers, shapes public opinion, and build a base of movement. Through these stages, INFEST and JBM conduct advocacy to change the regulation of protection of PMI.

\section{INTRODUCTION}

Since 2011 until 2017, the trend of sending Indonesian Migrant Worker/Pekerja Migran Indonesia (PMI) abroad has fluctuated. In 2011, Indonesia sent 586,802 migrant workers overseas. This amount had decreased in 2012 by 494,609, but it had returned to 512,168 in 2013. After 2013, the dispatch of migrant workers decreased by around one hundred to two hundred thousand. It was only in 2017 that the shipment of PMI abroad rose again to 262,899, after previously reaching 234,451 in 2016.

The majority of PMI distributed to the Middle East and Asia Pacific. Based on National Agency for Placement and Protection of Indonesian Workers/Badan Nasional Penempatan dan Perlindungan Tenaga Kerja Indonesia (BNP2TKI) data released on January 14, 2019, most of PMI were placed in four Asian countries namely Malaysia, Taiwan, Hong Kong, and Singapore. During 2016 to 2017, Malaysia has accommodated the largest PMI with a number of 267,285, followed by Taiwan with 212,283, Hong Kong with 139,649, and Singapore with 47,739. Saudi Arabia has experienced a decline in the number of PMIs due to the moratorium on sending PMI to the Middle East. The moratorium aims to limit the sending 
of informal PMIs (BNP2TKI, 2018). Meanwhile, from 2011 to 2015, Saudi Arabia was among the most recipient countries of PMI to replace Singapore, with a total accumulation of 291,209 PMI.

The number of PMI placement affects the total number of PMI abroad. According to data released by the World Bank in 2017, the number of PMI abroad is nine million, with 55\% working nonprocedurally (BNP2TKI, 2018). Non-procedural workers are the leading cause of complaints addressed to the government.

According to data released by BNP2TKI, PMI sent complaints regarding the protection of migrant workers. The protection referred to is not only related to violence, but also salary, and security of PMI rights. The following is the complaint data taken from 2011 until 2017.

Table 1 Number of Complaints of PMI Based on Types of Problems in 2011-2017

\begin{tabular}{|c|l|c|c|c|c|c|c|c|}
\hline No & \multicolumn{1}{|c|}{ Types of Problems } & $\mathbf{2 0 1 1}$ & $\mathbf{2 0 1 2}$ & $\mathbf{2 0 1 3}$ & $\mathbf{2 0 1 4}$ & $\mathbf{2 0 1 5}$ & $\mathbf{2 0 1 6}$ & $\mathbf{2 0 1 7}$ \\
\hline 1 & Sick/unhealthy & 253 & 298 & 293 & 258 & 314 & 312 & 246 \\
\hline 2 & Unpaid salary & 1.119 & 898 & 666 & 514 & 488 & 472 & 390 \\
\hline 3 & PMI want to be patriated & 307 & 1.029 & 1.055 & 817 & 524 & 357 & 428 \\
\hline 4 & Lost contact & 1.155 & 634 & 527 & 357 & 287 & 246 & 163 \\
\hline 5 & $\begin{array}{l}\text { Work is not in accordance with the } \\
\text { work agreement }\end{array}$ & 450 & 622 & 329 & 234 & 171 & 182 & 137 \\
\hline 6 & Layoffs & 75 & 147 & 147 & 90 & 167 & 705 & 227 \\
\hline 7 & PMI failed to leave & 85 & 84 & 96 & 134 & 658 & 143 & 248 \\
\hline 8 & Violence from the employer & 290 & 206 & 120 & 105 & 104 & 79 & 66 \\
\hline 9 & Overstay & 0 & 0 & 0 & 53 & 279 & 213 & 237 \\
\hline 10 & PMI had an accident & 47 & 97 & 89 & 94 & 95 & 77 & 50 \\
\hline 11 & Undocumented PMI & 35 & 30 & 120 & 73 & 81 & 133 & 373 \\
\hline 12 & PMI in prison/detention process & 88 & 97 & 60 & 63 & 46 & 57 & 57 \\
\hline 13 & $\begin{array}{l}\text { Not repatriated even though the } \\
\text { employment contract has expired }\end{array}$ & 0 & 0 & 0 & 41 & 177 & 121 & 44 \\
\hline 14 & $\begin{array}{l}\text { Salary deductions exceed the } \\
\text { provisions }\end{array}$ & 59 & 60 & 38 & 33 & 34 & 109 & 142 \\
\hline 15 & $\begin{array}{l}\text { Detention of passports or other } \\
\text { documents by PPTKIS }\end{array}$ & \begin{tabular}{l} 
Illegal recruitment of PMI \\
\hline
\end{tabular} & 88 & 56 & 50 & 39 & 55 & 70 \\
\hline
\end{tabular}


IJISH Vol. 2. No 1, April 2019 p. 32-49

\begin{tabular}{|c|l|c|c|c|c|c|c|c|}
\hline 17 & Run away from employer (Saudi) & 67 & 60 & 44 & 41 & 27 & 24 & 58 \\
\hline 18 & PMI has no money to travel home & 13 & 24 & 30 & 19 & 132 & 31 & 48 \\
\hline 19 & $\begin{array}{l}\text { PMI is not in harmony with the } \\
\text { employer }\end{array}$ & 57 & 40 & 45 & 47 & 20 & 23 & - \\
\hline 20 & Sexual harassment & 71 & 68 & 40 & 22 & 11 & 10 & - \\
\hline 21 & Human trafficking & - & - & - & - & - & 56 & 71 \\
\hline 22 & Job opportunity fraud & - & - & - & - & - & 40 & 39 \\
\hline 23 & Others Total & 396 & 910 & 640 & 794 & 1.203 & 1.307 & 1.196 \\
\hline
\end{tabular}

Source: (BNP2TKI, Data Penempatan dan Perlindungan PMI: Periode Bulan Desember Tahun 2018, 2019) and (BNP2TKI, Data Penempatan dan Perlindungan Tenaga Kerja Indonesia Tahun 2016, 2016)

From 2011 to 2017, the most PMI complaints were consistent in four countries, namely Saudi Arabia, Malaysia, Taiwan, and the UAE, with an accumulation of 27,844 complaints. Saudi Arabia ranked first with the highest number of complaints, 12,364. Then it was followed by Malaysia with several claims totaling 10,962 .

These problems occur due to inadequate management and lose regulations towards PMI protection. The majority of complaints problems are unpaid salaries, lost contact, work not according to work agreement, PMI wants to repatriated, violence from employers, layoffs, undocumented PMI, Sick, and PMI who fail to leave. According to the head of BNP2TKI, Nusron Wahid said that the government paid little attention to the protection of PMI rights (Munir, 2015). Most of the migrant workers who work in the informal sector, such as domestic worker, are women who are vulnerable to human trafficking, violence, and sexual harassment. Domestic workers are still the primary job choice, it was recorded that in 2018 , as many as 75,311 people became domestic workers. Besides, there are still many ambiguous regulations related to PMI, such as Law No. 39 of 2004 concerning the Placement and Protection of Indonesian Migrant Workers. The law is considered not to provide a detailed basis regarding protection against PMI and only focuses on the placement. Therefore, the government is considered less responsible for fulfilling PMI's protection rights.

Furthermore, agreements between Indonesia and the recipient countries of PMI are only based on the MoU. Meanwhile, most MoUs have different schemes as happened in Qatar. Qatar has Labor Law number 14 of 2004 which regulates Employment, but domestic workers are not regulated in the Act (Muthahari, 2014). This certainly narrows PMI's overseas protection efforts. For this reason, individual advocacy is needed to change PMI Indonesia's regulatory policies. 


\section{DISCUSSION}

\section{Public Policy Advocacy by Roem Topatimasang}

Public policy is a set of governance rules that govern interactions between the state and society. It is interpreted as an action taken by the stake-holder, to ensure that the objectives that have been formulated and agreed upon by the public can be achieved. This shows that public policy is not only understood as an administrative matter, but also understood as a political issue. Public policy is related to the use of power, therefore public policy takes place in a particular setting, with the aim of making stability and new achievement. A country without public policy is considered a failed state (Handoyo, 2012).

Meanwhile, if this public policy is harmed by the decision makers, then the society has the right to change or amend the policy. This will lead to the process of advocating a public policy. According to Roem Topatimasang, there are nine steps to change public policy, namely:

1. Forms core circle: a group of people and organizations that become initiators, movers and main controllers of all advocacy activities.

2. Selects strategic issues: There are five factors that must be fulfilled in choosing strategic themes: 1) actuality (which is becoming public's attention); 2) critical and urgent; 3 ) needs and aspirations that are often overlooked; 4) positive impact; 5) relevant to the vision and agenda of social change.

3. Designs goals/targets and strategies: advocacy process as an effort to change public policy, so that the formulation of its objectives (objective, targets, outcomes) should also adhere to its goals. Advocacy using soft ways, not using violence.

4. Processes data and packs information: this process is advocacy research in the form of policy studies. An advocacy actor needs to assess the impact of public policy and present its data in a short, concise, clear and firm structure. Then, the results of advocacy research will be submitted to policymakers.

5. Mobilizes allies and supporting unit: alliances in advocacy activities are individuals, groups or organizations that have the resources (expertise, access, power, information, infrastructure, and facilities, as well as funds), and then actively involved directly, supporting by taking a role or carrying out a certain function or task in the whole series of advocacy activities in an integrated manner. As for those who are not directly involved (for example, just helping with the provision of advice and logistics needed), it can be said to be a supporting unit.

6. Submits counter draft: There are three processes that must be taken to develop public policy. This section only discusses the first process, namely legislation and jurisdiction. The legislative process forms a legal draft or public policy covering several types of activities, namely, drafting a law or regulation, including the preparation of a counter draft, to a review or judicial review. The legislative process can involve the wider community in drafting counter draft legislation that will be submitted to policymakers to review previous public policies. 
7. Influences policymakers: efforts to influence policymakers can be done through lobbying, negotiation, mediation, collaboration, etc. carried out by advocacy actors. Until now, lobbying is still a powerful tool for influencing public policy. Lobbying can be done directly and indirectly. Direct lobbying can be done through personal meetings, telephone conversations, personal written letters, open letters, electronic messages, and revelations. Whereas, indirect lobbying is carried out through mass media campaigns, political campaigns with specific targets, professional assistance, community organizations, political parties, and mass demonstrations. At present many are starting to use online petitions to urge policymakers.

8. Shapes public opinion: In this pathway, forms of activities can be carried out in the form of campaigns for the formation of public awareness and public opinion, campaigns to raise support, training and political education on an issue to members and victims, the formation of organizational bases of movement, until the direction of mass forces does various solidarity actions, demonstrations, strikes, boycotts, social insubordination, and so on.

9. Build a base of movement: This section will focus the discussion on the aspects of mass base development of the advocacy movement, such as community organizing, political education and awareness, as the most essential part of the processes of socialization and mobilization to launch social and political pressure towards more impartial changes in public policy. The interests of the wider community (Topatimasang, Fakih, \& Rahardjo, 2016).

Following is the flow chart of integrated advocacy:

BAGAN ARUS ADVOKASI TERPADU

(Untuk disalin pada kertas plano/papan tulis transpamsi OHP)

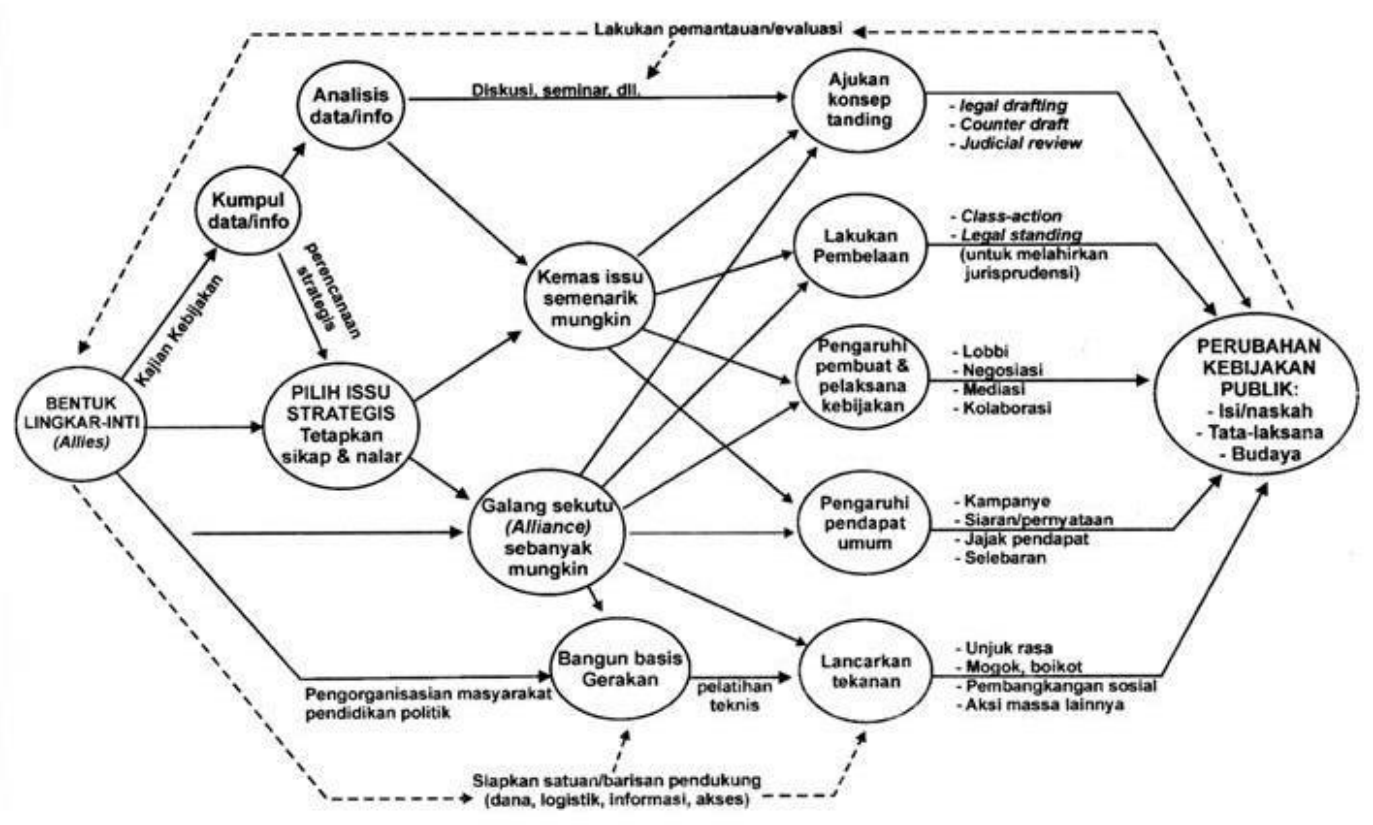




\section{Migrant Workers Policy and Management In Indonesia}

\section{Indonesian Labor Service Company/Perusahaan Jasa Tenaga Kerja Indonesia (PJTKI)}

In terms of PMI management, Indonesia established a private management body, namely Indonesian Labor Service Company/Perusahaan Jasa Tenaga Kerja Indonesia (PJTKI). PJTKI includes local private agents who manage PMI in full, ranging from recruitment, selection, training, until placement. This makes the illegal levies of migrant workers increasingly difficult to avoid because private agents hold full power in the management of migrant workers. The state only provides a place of work, not employment. However, the country directs the public to register with PJTKI to work overseas. A person cannot register for a job independently abroad, because he has to arrange a work permit certificate that must be taken through a recruitment agency. Indonesia is still difficult to change the migrant worker's management system. That is because state profits or foreign exchange flows indirectly amount to enormous amounts, which come from health insurance and others, monthly shipments from migrant workers to their families, and others.

\section{Legal Basis}

PMIs protected by various legal components. The workers covered by laws originating from the Office of Social Affairs, Labor and Transmigration, as well as protected by several rules and regulations related to labor. The following are the laws governing Indonesian employment matters.

Legal Basis Regarding Indonesian Migrant Workers:

1. Law No. 39 of 2004 concerning the Placement and Protection of Indonesian Migrant Workers;

2. Presidential Instruction No. 6 of 2006 concerning Reform Policy for Placement and Protection of Indonesian Migrant Workers Systems;

3. Government Regulation Number: 3 of 2013 concerning the Protection of Indonesian Workers Outside the Country;

4. Government Regulation Number 4 of 2013 concerning Procedures for Implementing Placement of Indonesian Workers Overseas by the Government;

The state has indeed stipulated many regulations relating to migrant workers, but it emphasizes more on the technical process of placing and sending migrant workers. Especially in Law No. 39 of 2004, the Act only addresses the placement of Indonesian migrant workers and the requirement of migrant workers, or it can be said that they are still oriented to the benefits of both parties without thinking of the rights of migrant workers when signing the MoU to destination countries. Even though the ILO has regulated the subject matter of the human rights of a worker who must still be fulfilled by the state, by not seeing labor as a commodity. 


\section{Advocacy Protection Process on Indonesian Labor by Institute For Education Development, Social, Religious, and Cultural Studies (INFEST)}

INFEST is one of the forum-based NGOs in reviewing their programs or based on solidarity. This includes affiliation with institutions that advocate for migrant workers, both locally, nationally and internationally. INFEST began to focus on the problem of migrant workers in 2010.

\section{Forms Core Circle}

INFEST build a core circle with Migrant Workers Network/Jaringan Buruh Migran (JBM) in 2010. JBM itself is a network of organizations and working groups that fight for effective protection for Indonesian migrant workers, wherever they are. This network is now led by the presidium, each of which has a different but interrelated task, namely the legalization of the protection of migrant workers, the handling of cases affecting migrant workers and the struggle to advance the interests of Indonesian migrant workers in various regional forums including ASEAN. JBM has 28 members who are oriented to workers at home and abroad, as follows: Asean Employees Services Trade Union Council (ASETUC), Assosiasi Serikat Pekerja Indonesia (Aspek Indonesia), FSPSI Reformasi, Human Rights Working Group (HRWG), Indonesia Migrant Workers Union (PMIU) Belanda, Jaringan Nasional Advokasi Pekerja Rumah Tangga (JALA PRT), Konfederasi Serikat Pekerja Indonesia (KSPI), Konfederasi Serikat Buruh Sejahtera Indoensia (KSBSI), Konfederasi Serikat Pekerja Seluruh Indonesia (KSPSI), Koalisi Tenaga Kerja Indoensia di Hongkong (KOTKIHO), Lembaga Bantuan Hukum (LBH) Jakarta, LBH Apik Jakarta, Lembaga Advokasi Buruh Migran (ADBMI) Lombok, Lembaga Penyadaran dan Bantuan Hukum Forum Adil Sejahtera (LPBH FAS), Migrant Institute, Perhimpunan Bantuan Hukum dan HAM Indonesia PBHI Jakarta, Serikat Buruh Migran Indoensia (SBMI), Solidaritas Perempuan, The Institute for Ecosoc Rights, Trade Union Rights Centre, Union Migrant Indoensia (UNIMIG), Serantau Malaysia, Perhimpunan Bantuan Hukum Buruh Migran (PBH-BM), Buruh Migran Indonesia Saudi Arabia (BMI SA), Institute of Education Development, Social, Religious \& Cultural Studies (INFEST) Yogyakarta, Seruni Banyumas, Serikat Buruh Migran Indonesia Wonosobo (SBMI Wonosobo), and Migrant Aids Indonesia.

Initially, starting in 2010, JBM focused its struggle on the national legislation program, which included the Legislative initiative to revise Law No. 39 of 2004 concerning the Placement and Protection of Indonesian Migrant Workers Abroad/Penempatan dan Perlindungan Tenaga Kerja Indonesia di Luar Negeri (PPTKILN). This situation encourages civil society groups consisting of components of trade unions/labor unions, migrant trade unions, academics, and NGOs to oversee the legislative process by uniting themselves in an advocacy network. The network formed since February 2010 was later agreed to be named the Advocacy Network for the Revision of the Placement and Protection of Indonesian Migrant Workers Act/Jaringan Advokasi Revisi Undang-Undang Penempatan dan Perlindungan TKI (JARI PPTKILN). JARI-PPTKILN later renamed JBM in 2014, in order to widen the range of advocacy. INFEST collaborated with JBM regarding the revision of Law No. 39/2004. 


\section{Select Strategic Issues}

1. Non-detailed and Loose Regulations

The regulation that specifically addresses the protection of migrant workers is Law No. 39 of 2004 concerning Placement and Protection of Indonesian Migrant Workers Abroad. However, in fact, the Act does not have an academic text, because it is derived from the Decree of the Minister of Manpower and Transmigration No. 104A/Men/2002 Regarding the Placement of Indonesian Migrant Workers Abroad (Ma'arif, UU 39 Tahun 2004 Tentang PPTKILN Tak Memiliki Naskah Akademik, 2015). The term is often referred to as the Ministerial Decree, so the content is exactly the same as the Decree. As a result, the law does not regulate comprehensively.

This non-detailed regulation raises the assumption that the state only sees PMI as a commodity, so the rules do not pay attention to PMI rights. According to Bahrain, Advocacy Director of the Indonesian Legal Aid Foundation/Yayasan Lembaga Bantuan Hukum Indonesia (YLBHI), stated that most PMI problems were caused by wrong policies. This was justified by Iskandar Zulkarnaen of FSPILN, who added that in defending the PMI it must be carried out systematically to policy problems (Zink, 2013).

\section{Deficient PMI management from Government and PJTKI}

PMI recruitment and training are still charged to PJTKI, whereas PJTKI is business oriented, not socially oriented. Thus, when PJTKI gets 100 Job Orders, it must be immediately fulfilled or it will lose. In the fulfillment process, PJTKI recruited, trained, and then placed prospective migrant workers who did not meet the requirements. As a result, PMI will not be protected. The position of the PJTKI must be placed as the sending institution only. Recruitment, training, health tests and psychology, must be conducted by the Pre-Placement Institute to minimize the possibility of future problems (Ma'arif, UU 39 Tahun 2004 Tentang PPTKILN Tak Memiliki Naskah Akademik, 2015).

Also, Bobi AM, Secretary-General of the SBMI DPN, stressed that the government was giving too much authority to PJTKI, which caused problems in the future. For placement issues, for example, the PMI sector as domestic workers is the most extensive placement in the hands of the private sector, while the placement of formal workers whose human resources tends to be more knowledgeable, is actually placed or managed by the government G to G (Zink, 2013).

\section{Designs Goals/Targets and Strategies}

INFEST, and JBM have advocated public policy regarding the protection of migrant workers in Law No. 39 of 2004. They demanded that the government immediately amend the Act. The draft law has been sent to the center but has never been discussed in the National Legislation Program. In 2016, the DPR is currently revising the law and promises to be completed in 2017 . About $60 \%$ of the law talks about the placement of migrant workers, never brings up humanitarian issues, and always delegates them 
to private parties, so that crime or levies wild from the private sector is getting bigger and detrimental to migrant workers.

Therefore, the mission of JBM are:

1. Actively taking part in overseeing the creation, implementation, monitoring, and evaluation of policies for the protection of Indonesian migrant workers. It includes writing counter draft legislation in JARI-PPTKILN version.

2. Take an active role in encouraging the implementation of the responsibility of the state in the protection of Indonesian migrant workers.

3. Conduct lobbying and hearings to the government, parliament, and the media.

4. Conduct workshops and discussions related to Draft Law No.39 of 2004:

\section{Processes Data and Packs Information}

JBM criticized the low commitment of the government which was clearly illustrated by the substance of the Problem Inventory List/Daftar Inventaris Masalah (DIM) and the Draft Law on Indonesian Overseas Workers/Rancangan Undang-Undang Pekerja Indonesia di Luar Negeri (RUU PPILN) that the government had submitted to the Indonesian Parliament on February 6, 2013

The following are criticized DIM points:

1. There is no change in the title of Law No.39 of 2004. Thus, the legal substance will not reflect the protection of migrant workers but still makes migrant workers a commodity.

2. Indonesia has ratified the United Nations Convention on the Protection of Migrant Workers and Members of Their Families, but in the government version of the draft does not include the convention in consideration.

3. The definition of migrant workers in the draft bill does not describe a series of migration processes starting from the country of origin, the country of work, to returning to the country of origin as contained in the convention. The draft bill defines migrant workers only to meet certain requirements, does not describe the situation and scope of workers migrating to other countries.

4. Based on that definition, the scope of protection in this draft bill is only from the time of recruitment to returning home only. Whereas the purpose of protection is to increase the welfare of migrant workers, including how the efforts of the government to empower returned migrant workers, including to be able to manage the results of work abroad.

5. This draft provides many rights for migrant workers, but it is not clear who will be responsible for fulfilling the rights of migrant workers. 
6. The draft bill does not clearly stipulate the process of recruiting migrant workers. This bill only mentions that there are recruitment activities, but it is not clear who will recruit, register and select prospective migrant workers.

7. This bill eliminates the conditions of migrant workers regarding the KTKLN (Foreign Workers Card/Kartu Tenaga Kerja Luar Negeri), but at the same time this draft adds the condition that migrant workers must have SKPLN (Certificate of Moving Abroad/Surat Keterangan Pindah Luar Negeri). SKPLN requirements are like legally expelling their citizens to other countries, which has an impact on the removal of the rights of migrant workers as citizens. Not only that, the draft bill also requires SKCK (Letter of Police Notes/Surat Keterangan Catatan Kepolisian) regarding good behavior. This will aggravate prospective migrant workers and encourage illegal levies for prospective migrant workers.

8. The draft bill does not clearly regulate the role of the PJTKI in the entire migration process, as well as the roles and responsibilities of protecting migrant workers.

9. Regulations regarding the funding component that must be borne by each party, namely migrant workers, users and the government are still unclear, especially the costs of education and training, even though the highest cost component is the cost of education and training, which results in high wages for migrant workers.

10. Provisions regarding education and training for migrant workers are not placed in separate chapters. This shows that education and training are not an important part of the large framework of protection of migrant workers.

11. There is no regulation regarding the duties and authority of the government and regional government in protecting migrant workers. The Central Government has not yet answered the issue of the difficulty of coordination between relevant ministries, and how the role is shared with the regional government.

12. It is unclear mechanism of data collection and supervision of the protection of the rights of migrant workers (Redaksi, Berita: Pusat Sumber Daya Buruh Migran, 2013).

13. The government must include elements of the stages of migration in the bill. Migration of labor abroad is divided into three stages that are regulated by each responsible institution, namely: the preplacement period is managed by the Pre-Placement Institution, the placement period is regulated by the Placement Institution and after placement is arranged by the Full Placement Institute (Ma'arif, UU 39 Tahun 2004 Tentang PPTKILN Tak Memiliki Naskah Akademik, 2015). 


\section{Mobilizes Allies and Supporting Units}

JBM attempts to build alliances by attending several activities held by other organizations, as well as actively collaborating with external parties. JBM built an alliance with the BPJS Employment Board and Migrant Care to discuss Social Security for PMI. Then, JBM also collaborated with SBMI, Kabar Bumi, Komnas Perempuan, KPI, and Migrant Care to criticize the contents of the PPMI Bill. In spite of that, JBM together with BPJS Watch compiled campaign instruments on social security for Indonesian migrant workers. JBM also attended discussions on the Revision of Law No. 39 of 2004 held by IFN, IDN, HOME, TWC2, and the Indonesian Embassy Singapore at the Indonesian Embassy Hall in Singapore.

\section{Submits Counter Draft}

In June 2015, JBM gave input on the bill through a legal drafting team from the DPR General Secretariat which was currently drafting a draft bill No.39 of 2004. JBM activists were also actively present, September 2017 in Jakarta, drafting a strategic plan to fight for articles on the protection of migrant workers into the PPMI Bill. Then, JBM was also invited by the Panja of the PPMI Bill in the DPR RI. JBM proposes a draft containing the general principle of the convention is non-discrimination, not only for migrant workers but also for family members and the government's duty to fulfill the rights of Indonesian migrant workers to be part of the PPMI Bill (Jejaring Buruh Migran, 2018).

\section{Influences Policy Makers}

JBM conducts several activities, such as negotiations, discussions, and workshops, in influencing policymakers. During the Meeting of the RUU PPILN in Senayan on 26 February 2013, activists of migrant workers including the Migrant Workers Resource Center/Pusat Sumber Daya Buruh Migran (PSD-BM), JARI-PPTKLN, SBPN DPN, Migrant Care, and others have taken anticipatory steps by holding action in front of the Indonesian Parliament building. This action was carried out to demand a government version of the Indonesian Migrant Worker Bill which still discriminates against migrant workers. During this time, the contents of the Law on Indonesian Migrant Workers never mentioned the existence of labor organizations, even though the actions taken had more influence on the situation of migrant workers, compared to the steps taken by the government (Ikhtiyarini, Aksi Pegiat Buruh Migran Sebelum Sidang RUU PPILN, 2013).

Besides that, several discussions were also held, including:

1) Discussion of the tasks of the Regional Government. One of them is about the One-Stop Integrated Services/Layanan Terpadu Satu Atap (LTSA) with regional autonomy to input the PPMI Bill.

2) Discussion on the separation of regulators and operators, LTSA, state-handed insurance, cheap financing for PMI, protection of Indonesian migrant domestic workers according to the 1990 UN convention. 
3) November 2015, hearings with the Panja Chairperson of the PPMI Draft Bill talked about the protection of PMI who worked independently, protection for Fish Boat Crew/Anak Buah Kapal (ABK), LTSA and articles regarding the elimination of the KTKLN in the Draft Bill.

4) January 2016, hearings with the Nasdem Party about insurance for PMI and ABK Protection. JBM requests for including PMI and $\mathrm{ABK}$ into the protection scheme because of work vulnerability and contribution in the Indonesian economy.

5) January 2016, hearings to the Ministry of Foreign Affairs concerning PMI Protection abroad, especially in handling cases and supervision through overseas agency verification.

6) Audience to BNP2TKI about high costs for PMI.

7) 25 October 2016, hearings with the Minister of Manpower to discuss the division of the roles of regulators and operators so as not to overlap and coordinate mechanisms at the central and regional levels.

8) Hearings with KPPPA to discuss gender perspectives in the PPMI Bill and Protection for migrant of domestic workers.

9) Hearing with Kemko PMK discussed the importance of protecting trafficked PMIs and improving migrant governance in the PPMI Bill (Jejaring Buruh Migran, 2018).

\section{Shapes Public Opinion}

JBM has held several activities to shape public opinion, including:

1. Press Conference on 2015 International Migrant Workers Day which has the theme of strengthening the country to protect migrant workers through the implementation of the 1990 UN convention (Law No. 6 of 2012) into the draft bill and its derivative regulations. JBM requested support from various parties to oversee the bill.

2. Press Conference on 2016 International Migrant Workers Day, with the theme of asking the House of Representatives/DPR and the government to seriously discuss the contents of the revision of Law No.39 of 2004 in accordance with the 1990 UN conventions and CEDAW. As an evaluation it strengthens the impoverishment of women and increases the chances of trafficking in 2015.

3. Press Conference on 2016 International Labor Day, with the theme of the right of migrant workers to work and earn wages appropriately, through evaluating and improving the management of migrant labor migrations from upstream to downstream with the principles of good governance, openness, transparency, non-discrimination, and fulfillment of rights for migrant workers.

4. Media roadshow to Antara news agency. JBM delivered ten crucial issues in the PPMI Bill which needed to be improved and asked for media participation to oversee the discussion of the PPMI Bill.

5. Campaigns through the labormigrant.or.id and pantaupjtki.com website formed by INFEST as an information spreader. Also, JBM itself contains all information on its website. 
6. JBM campaigned on the importance of decent work for all workers, especially migrant workers who work as domestic workers and crews at the Global Forum on Migration and Development in Turkey 2015 (Jejaring Buruh Migran, 2018).

\section{Build A Base of Movement}

Forming the basis of the movement is the result of public opinion that has been shaped. Thus, paralegals come under the auspices of INFEST to help resolve PMI cases in other countries. Paralegals are former PMI who have been caught in legal cases, then helped other PMI with similar cases. In addition, the base of movement can also be seen from public awareness of the importance of the issue of migrant workers. At the commemoration of the International Migrant Workers Day every December, JBM moves towards state palace to express concern that the country is still half-hearted in protecting its workers outside the country.

Furthermore, Serantau Malaysia held seminar and discussion at the Kuala Lumpur Indonesian School in 2016, with the theme Advocacy and Documentation of the Case of Indonesian Migrant Workers in Malaysia. The training was organized by PSD-BM supported by the Tifa Foundation. Director of Infest, Muhammad Irsyadul Ibad and Eddy Purwanto from the Legal Aid Center for Migrant Workers (PBH BM) became a facilitator in this training (Maulita, 2016).

\section{Achievement of Public Policy Advocacy in Law No. 39 of 2004}

Law No. 39 of 2004 concerning Placement and Protection of Indonesian Migrant Workers Abroad changed to Law No.18 of 2017 concerning Protection of Indonesian Migrant Workers/Perlindungan Pekerja Migran Indonesia (PPMI). The difference between the two laws can be observed from the existence of specific chapters and articles on the protection of migrant workers, migrant workers' rights, social security, duties and responsibilities of the central government and regional governments, one-stop integrated services for the placement and protection of Indonesian migrant workers. The new law emphasizes the role of the government in the placement and protection of PMI, and reduces the role of the private sector. Both central and regional governments are obliged to protect PMI starting from before work, during work and after work. The private sector was only given the role of implementing the placement of PMI (Ratnaningsih, 2017).

According to JBM, there are significant changes from the approved PPMI Bill, including:

1) The definition of migrant workers and family members (land and sea) is in accordance with the 1990 UN convention.

2) The 1990 UN Convention was included in the consideration, so that the recognition of the rights of migrant workers was more numerous, one of which was freedom of association, and social, economic and legal protection. 
3) Education and training are the responsibility of the government (previously PJTKI), this will improve the skills of prospective migrant workers not only a formality, and reduce placement costs by up to 8 million.

4) Information service on employment and data collection from the village government.

5) There is clarity on the division of authority of operators and regulators (Ministries and Agencies), as well as the division of duties and authorities of the central, provincial, regional and village governments.

6) TKI insurance regimes are replaced with BPJS.

7) LTSA services in the regions, so it does not have to be done at the Center.

8) Removing the KTKLN, a card that is often used for extortion of migrant workers.

9) Strengthening the role of Labor Attache abroad.

10) There is agency verification and prospective employers in endorsing job orders by Labor Attaches.

11) Reducing the role of PJTKI.

12) Sanctions are imposed not only for corporations but also for officials.

13) Officials who have the authority to conduct placement and protection are prohibited from concurrently acting as commissioners/administrators of placement companies.

However, there are still weaknesses from the ratification of this Act according to JBM, namely:

1) The placement mechanism still has to be conducted by PJTKI. Domestic workers cannot yet become independent workers, they still have to go through a PJTKI.

2) The employment agreement has not ensured its implementation in both countries and the dispute resolution mechanism has not included quasi-judicial.

3) Social security does not cover the risks often experienced by migrant workers, namely unilateral layoffs and unpaid salaries.

4) The involvement of community participation is still weak in implementing safeguard supervision.

5) Criminal sanctions still have weaknesses such as; Some sanctions do not include a minimum sentence, consequently the decision depends on the judge. Corporate management is not convicted. Legal assistance regulated in the article of rights, is not regulated in a special chapter on legal assistance for Indonesian migrant workers. So the way to access, which institution to go to, how long the dispute resolution is, whether accompanied by a lawyer or not is still confusing.

6) In the dispute resolution mechanism, the government does not make a quasi-judicial and has the potential to free responsibility of protection for migrant workers. (Article 77 paragraph 3: if no agreement is reached, it can file a claim through the court).

7) For institutions, tasks and functions of the central and regional governments; it has not been regulated regarding the duties of the regional government to handle cases. Hopefully this can be realized in LTSA. The central government has not been mandated to make an integrated data system from the village to abroad (Redaksikr, 2017). 


\section{Latest Developments in Implementing Law No. 18 of 2017 in 2018}

UU no. 18 of 2017 has been ratified, but the implementation of the Act has not yet been conducted. Government Regulation/Peraturan Pemerintah (PP) as implementing rules has not been issued. On September 18, 2018, Chairman of the House of Representatives Commission IX Dede Yusuf Macan Effendi in a discussion at the Parliament Building Complex, said that the regulation in the form of PP should have been issued in August 2018. Unfortunately, the government did not issue PP.

Coordinator of the Migrant Care Policy Advocacy Division, Siti Badriyah, asked the government to immediately issue a PP as the executor of the PPMI Law. Moreover, currently cases of employment PMI in other countries continue to increase, 264,092 cases of complaints from PMI were recorded in 2018. While the protection of migrant workers has not been maximized. Deputy of BNP2TKI Protection, Anjar Prihantoro acknowledged that the implementation of the PPMI Law was still waiting for the government to issue PP. Through the PP, the president will form a special body mandated by Article 46 of the PPMI Law. Article 46 paragraph (1) states, "The task of protecting Indonesian migrant workers is carried out by a body established by the President". While paragraph (2) states, "The agency as referred to in paragraph (1) is headed by the head of the Agency appointed by the President and responsible to the President through the Minister"(Hidayat, 2018).

\section{CONCLUSION}

Public policy advocacy on Law No. 39 of 2004 concerning the Placement and Protection of Indonesian Migrant Workers Abroad has been successful. The law was replaced by Law No.18 of 2017 concerning the Protection of Indonesian Migrant Workers (PPMI). JBM has advocated through negotiations, discussions, and hearings with various groups to forge alliances and strengthen the base of the movement. In addition, the activity was also aimed at influencing policymakers to immediately revise the Law.

\section{REFERENCES:}

Alwy, B. (2015, September 28). Standar Perjanjian Kerja yang Memperbudak Buruh Migran. Retrivied February 23, 2019, from Pusat Sumber Daya Buruh Migran: https://buruhmigran.or.id/2015/09/28/standar-perjanjian-kerja-yang-memperbudak-buruhmigran/

BNP2TKI. (2011, February 27). Publikasi: BNP2TKI. Retrivied February 23, 2019, fromi BNP2TKI: http://www.bnp2tki.go.id/frame/9003/Sejarah-Penempatan-TKI-Hingga-BNP2TKI

BNP2TKI. (2011, February 27). Sejarah Penempatan TKI Hingga BNP2TKI. Retrivied February 23, 2019, from BNP2TKI: http://www.bnp2tki.go.id/frame/9003/Sejarah-Penempatan-TKI-HinggaBNP2TKI 
BNP2TKI. (2016). Data Penempatan dan Perlindungan Tenaga Kerja Indonesia Tahun 2016. Jakarta: BNP2TKI.

BNP2TKI. (2018, March 12). Publikasi: BNP2TKI. Retrivied February 21, 2019, from BNP2TKI: http://www.bnp2tki.go.id/read/13060/Rp-108-Triliun-Remitansi-TKI-Tahun-2017.html

BNP2TKI. (2019). Data Penempatan dan Perlindungan PMI: Periode Bulan Desember Tahun 2018. Jakarta: BNP2TKI.

Cahyu. (2018, February 8). Menaker Jelaskan Moratorium Penempatan TKI ke Timur Tengah. Retrivied February 24, 2019, from Liputan6: https://www.liputan6.com/news/read/3268392/menakerjelaskan-moratorium-penempatan-tki-ke-timur-tengah

Fadli, A. (2013, March 28). Kisah Penahanan Dokumen Oleh PJTKI. Retrivied February 23, 2019, from Pusat Sumber Daya Buruh Migran: https://buruhmigran.or.id/2013/03/28/kisah-penahanandokumen-oleh-pjtki/

Handoyo, E. (2012). Kebijakan Publik. Semarang: Widya Karya.

Hidayat, R. (2018, September 19). Implementasi Perlindungan Pekerja Migran Terganjal Aturan Pelaksana. Retrivied February 26, 2019, from Hukumonline.com: https://www.hukumonline.com/berita/baca/lt5ba1fd182affe/implementasi-perlindunganpekerja-migran-terganjal-aturan-pelaksana

Ikhtiyarini, P. (2013, February 26). Aksi Pegiat Buruh Migran Sebelum Sidang RUU PPILN. Retrivied February 23, 2019, from Pusat Sumber Daya Buruh Migran: https://buruhmigran.or.id/2013/02/26/aksi-pegiat-buruh-migran-sebelum-sidang-ruu-ppiln/

Ikhtiyarini, P. (2013, January 22). Berita: Pusat Sumber Daya Buruh Migran. Retrivied February 23, 2019, from Pusat Sumber Daya Buruh Migran: https://buruhmigran.or.id/2013/01/22/ppperlindungan-tki-di-luar-negeri-telah-terbit/

Ikhtiyarini, P. (2013, November 29). Bukti BNP2TKI Tidak Jalankan Fungsi Pemantauan TKI. Retrivied February 23, 2019, from Pusat Sumber Daya Buruh Migran: https://buruhmigran.or.id/2013/11/29/bukti-bnp2tki-tidak-jalankan-fungsi-pemantauan-tki/

Ikhtiyarini, P. (2014, February 12). Kewajiban Perwalu RI dalam Melindungi Hak-Hak BMI. Retrivied February 23, 2019, from Pusat Sumber Daya Buruh Migran: https://buruhmigran.or.id/2014/02/12/kewajiban-perwalu-ri-dalam-melindungi-hak-hak-bmi/

Ikhtiyarini, P. (2014, April 7). MoU Indonesia-Malaysia, Belum Lindungi Hak-Hak BMI. Retrivied February 23, 2019, from Pusat Sumber Daya Buruh Migran: https://buruhmigran.or.id/2014/04/07/mou-indonesia-malaysia-belum-lindungi-hak-hak-bmi/

Ikhtiyarini, P. (2014, January 16). Pencabutan Moratorium dan Kesepakatan MoU dengan Arab. Retrivied February 23, 2019, from Pusat Sumber Daya Buruh Migran: https://buruhmigran.or.id/2014/01/16/pencabutan-moratorium-dan-kesepakatan-mou-denganarab/ 
Ma'arif, B. A. (2013, January 25). Berita: Pusat Sumber Daya Buruh Migran. Retrivied February 23, 2019, from Pusat Sumber Daya Buruh Migran: https://buruhmigran.or.id/2013/01/25/ktklnpemerasan-atau-pelayanan/

Ma'arif, B. A. (2013, January 31). Berita: Pusat Sumber Daya Buruh Migran. Retrivied February 23, 2019, from Pusat Sumber Daya Buruh Migran: https://buruhmigran.or.id/2013/01/31/icmc-gelardialog-publik-setahun-ratifikasi/

Ma'arif, B. A. (2013, February 4). Berita: Pusat Sumber Daya Buruh Migran. Retrivied February 23, 2019, from Pusat Sumber Daya Buruh Migran: https://buruhmigran.or.id/2013/02/04/kawalrevisi-rebut-hak-tki/

Ma'arif, B. A. (2015, October 25). UU 39 Tahun 2004 Tentang PPTKILN Tak Memiliki Naskah Akademik. Retrivied February 23, 2019, from Pusat Sumber Daya Buruh Migran: https://buruhmigran.or.id/2015/10/25/uu-39-tahun-2004-tentang-pptkiln-tak-memiliki-naskahakademik/

Maulita, T. (2016, March 23). Komunitas Serantau Belajar tentang Advokasi dan Pendokumentasian Kasus. Retrivied February 23, 2019, from Pusat Sumber Daya Buruh Migran: https://buruhmigran.or.id/2016/03/23/komunitas-serantau-belajar-tentang-advokasi-danpendokumentasian-kasus/

Migran, J. B. (2018, April 25). Perjalanan Jaringan Buruh Migran dalam Mengawal Undang-Undang Pelindungan Pekerja Migran Indonesia. Retrivied March 1, 2019, from Jejaring Buruh Migran: https://www.youtube.com/watch?v=mlhMu8e4NNY

Munir, M. (2015, October 4). Ekonomi: MetroTVNews.com. Retrivied February 22, 2019, from MetroTVNews.com: http://ekonomi.metrotvnews.com/read/2015/10/04/176703/remitansi-tkiakhir-desember-diyakini-capai-usd10-m

Muthahari, N. (2014, August 6). Hukum Ketenagakerjaan Qatar. Retrivied February 23, 2019, from Pusat Sumber Daya Buruh Migran: https://buruhmigran.or.id/2014/08/06/hukum-ketenagakerjaanqatar/

Ratnaningsih, E. (2017, December 31). Paradigma Baru Perlindungan Pekerja Migran Indonesia. Retrivied February 26, 2019, from Binus University Faculty of Humanity: http://businesslaw.binus.ac.id/2017/12/31/paradigma-baru-perlindungan-pekerja-migran-indonesia/

Ratya, M. P. (2017, September 29). Berita: DetikNews. Retrivied February 15, 2019, from DetikNews: https://news.detik.com/berita/d-3664486/beragam-aduan-tki-kekerasan-majikan-hingga-takpunya-ongkos-pulang

Redaksi. (2013, February 25). Berita: Pusat Sumber Daya Buruh Migran. Retrivied February 23, 2019, from Pusat Sumber Daya Buruh Migran: https://buruhmigran.or.id/2013/02/25/siaran-pers-jaripptkln/

Redaksi. (2013, April 9). Political Will Pemerintah Tak Ada, Revisi Atau Pengulangan? Retrivied February 23, 2019, from Pusat Sumber Daya Buruh Migran: https://buruhmigran.or.id/2013/04/09/political-will-pemerintah-tak-ada-revisi-ataupengulangan/ 
Redaksi. (2013, February 27). UU PPTKILN Timbulkan Perbudakan Utang Atau Debt Bondage. Retrivied February 23, 2019, from Pusat Sumber Daya Buruh Migran: https://buruhmigran.or.id/2013/02/27/uu-pptkiln-timbulkan-perbudakan-utang-atau-debtbondage/

Redaksi. (2014, January 17). Daftar PPTKIS yang Dicabut Izin Pengerahannya. Retrivied February 23, 2019, from Pusat Sumber Daya Buruh Migran: https://buruhmigran.or.id/2014/01/17/daftarpptkis-yang-dicabut-izin-pengerahannya/

Redaksikr. (2017, October 25). RUU Perlindungan Pekerja Migran Indonesia Sah Menjadi UU, JBM Apresiasi Namun Nilai Masih Banyak Kelemahanya. Retrivied February 25, 2019, from Kemajuanrakyat.co.id: https://www.kemajuanrakyat.co.id/ruu-perlindungan-pekerja-migranindonesia-sah-menjadi-uu-jbm-apresiasi-namun-nilai-masih-banyak-kelemahanya/

Sahude, S. (2014, June 28). Referensi: Migrant Care. Retrivied February 23, 2019, from Migrant Care: http://www.migrantcare.net/2014/06/inpres-ri-no-62006-tentang-kebijakan-reformasi-sistempenempatan-dan-perlinudngan-tki/

Topatimasang, R., Fakih, M., \& Rahardjo, T. (2016). Mengubah Kebijakan Publik: Panduan Pelatihan Advokasi. Yogyakarta: INSISTPress.

Wahyudi, R. (2016, August 22). Moratorium Penempatan PRT Migran dan Kebijakan Zero PRT 2017. Retrivied February 23, 2019, from Pusat Sumber Daya Buruh Migran: https://buruhmigran.or.id/2016/08/22/moratorium-penempatan-prt-migran-dan-kebijakan-zeroprt-2017/

Winarto, Y. (2017, July 12). Revisi UU Perlindungan TKI Kembali Jalan. Retrivied February 23, 2019, from Kontan.co.id: https://nasional.kontan.co.id/news/revisi-uu-perlindungan-tki-kembali-jalan

Zink, H. (2013, September 21). Jejaring Organisasi Buruh Migran Bentuk Tim Penyelamat BMI. Retrivied February 23, 2019, from Pusat Sumber Daya Buruh Migran: https://buruhmigran.or.id/2013/09/21/jejaring-organisasi-buruh-migran-bentuk-tim-penyelamatbmi/ 